\title{
Quetiapine Fumarate
}

National Cancer Institute

\section{Source}

National Cancer Institute. Quetiapine Fumarate. NCI Thesaurus. Code C47700.

The fumarate salt form of quetiapine, a dibenzothiazepine derivative with antipsychotic property. Quetiapine fumarate antagonizes serotonin activity mediated by 5-HT 1A and 5-HT2 receptors. With a lower affinity, this agent also reversibly binds to dopamine D1 and $D 2$ receptors in the mesolimbic and mesocortical areas of the brain leading to decreased psychotic effects, such as hallucinations and delusions. In addition, quetiapine fumarate also binds to other alpha-1, alpha-2 adrenergic and histamine $\mathrm{H} 1$ receptors. 